European journal of American studies

Special Issue: Truth or Post-Truth? Philosophy, American Studies, and Current Perspectives in Pragmatism and Hermeneutics

\title{
Is Truth to Post-Truth what Modernism Is to Postmodernism? Heidegger, the Humanities, and the Demise of Common-Sense
}

\author{
Klaus Benesch
}

\section{OpenEdition}

\section{Journals}

Electronic version

URL: https://journals.openedition.org/ejas/15619

DOI: 10.4000/ejas.15619

ISSN: 1991-9336

\section{Publisher}

European Association for American Studies

\section{Electronic reference}

Klaus Benesch, "Is Truth to Post-Truth what Modernism Is to Postmodernism? Heidegger, the Humanities, and the Demise of Common-Sense", European journal of American studies [Online], 15-1 2020, Online since 11 May 2020, connection on 08 July 2021. URL: http://journals.openedition.org/ ejas/15619 ; DOl: https://doi.org/10.4000/ejas.15619

This text was automatically generated on 8 July 2021 .

Creative Commons License 


\title{
Is Truth to Post-Truth what Modernism Is to Postmodernism? Heidegger, the Humanities, and the Demise of Common-Sense
}

\author{
Klaus Benesch
}

1 Truth or post-truth? For most readers, the question raised in the title of this collection conveys a sense of uneasiness about the current state of affairs-political, social, cultural-in that it juxtaposes two mutually exclusive world views: one based on facts and on largely reliable representations of these facts, and another that posits a postfactual world full of fake news and disinformation in which rivaling versions of reality are in ongoing competition. It also asks us to choose between these two worlds, as if we still had a choice, and both the world of truth and the world of post-truth were equally available to us, either to be nurtured or rejected. What if, however, the collocation of these two possible worlds is but a false proposition, not unlike asking: modernism or postmodernism? Since the "post" in postmodernism evokes an irredeemable lapse of time, a transformation that has already taken place, it can hardly be reversed. In other words, there is no going back to modernism (or truth, for that matter) if you believe that such a thing as postmodernism (or post-truth) really exists. You may prefer the former, but history will not let you choose between the two, modernism will always remain-even if preferred over its later, distorted twin-an option that is no longer an option.

2 To consider post-truth an adequate description of our own time suggests an equally irreversible transformation of society, the change from a previous, bygone era of truth to a contemporary social and cultural environment predicated on alternative notions of truth, such as "fake news," "alternative facts," or my personal favorite "truthiness," a fake word invented by the comedian Stephen Colbert who parodied cable news talk shows on his own, now discontinued cable show The Colbert Report. Let's assume, for the sake of argument, that at an earlier stage of modern society, truth once reigned 
supreme. We would then have to explain how the new paradigm of post-truth has finally come to prevail and, perhaps more importantly, why we think that truth is a socially desirable good that should be embraced and-if now lost-somehow recuperated. In so doing, we should also ask to what extent the notion of post-truth is substantially different or at least substantially distinct from previous experiences of truth, both individual and collective. Moreover, there is the issue of a possible causality, as in: does post-truth follow from truth as postmodernism follows from modernism? If the answer is "yes," then any attempt to retrieve some of the values associated with the era of truth, such as veracity, accountability, authenticity, etc., would be all but futile. If, on the other hand, the causal relations between these two historical moments turn out to be rather weak, social remedies for the current transformation of society and its negative consequences seem much less far-fetched. Finally, whether we worry about the watering down of the notion of truth or whether we embrace post-truth as our new reality, we should be altogether wary of mingling abstract philosophical ideas with matters of politics and cultural change. To ask about truth or post-truth is not the same as asking: what do and what can we know about the world as it appears to us?-issues philosophers have been struggling with for centuries. What is frequently lacking in current debates on the specters of a post-truth society are efforts to re-envision the social contract underlying all modern democratic societies. For any successful participatory involvement in political action not only requires fundamental democratic rights such as the freedom of speech; it also turns on a shared understanding of the ultimate goals of politics and, equally important, on a meaningful public conversation about the ways and means by which to achieve these goals.

In what follows, I argue that there is no such thing as post-truth. We are by no means in the middle of an unprecedented epistemological crisis that keeps us from telling right from wrong. Rather, what we are currently witnessing is a major breakdown of the institutions and mechanisms of democratic society, triggered by an encompassing technological transformation that affects both our public and our private lives. True, in its wake, truth claims have become increasingly contested and way more difficult to uphold. Even if the challenges for rational public discourse are real, however, they should not be countered by philosophy but by concerted, serious interventions into political processes. My approach to the issue of post-truth, therefore, is threefold: first, I look at how most of us in "the West" have come to agree on certain truths about truth. As Martin Heidegger observed, our understanding of truth has often been too narrowly focused on the correspondence between a statement and an object that is deemed immutable and fixed. In a crucial passage of Being and Time Heidegger instead posits an inextricable linkage between truth and un-truth, neither of which could be completely separated from the other nor used interchangeably. And since the notion of post-truth is often invoked to expose someone who fails to speak the truth (rather than to demote the concept of truth as such), I also consider the Greek tradition of parrhesia, as discussed by the late Michel Foucault. Here, I am particularly interested in the role of "truth-speaking" as a form of critique, a rhetorical tool to positively intervene in social and political discourses.

4 Second, I briefly comment on a recent cultural phenomenon, the alarming rise of antiprofessionalism, which for many is closely connected to the unlimited availability of professional knowledge online. As I argue, anti-professional, anti-elitist sentiments coupled with an increasing distrust in academic expertise have paved the way for an allegedly post-factual world and, ultimately, have nibbled away at the authority of 
professionals and experts altogether. Long before Donald Trump waged war on the university, the erosion of expertise, according to a remarkably prescient 2004 essay by Bruno Latour, has been fostered-at least in part-by forces unleashed within the humanities and other fields of academic inquiry itself. ${ }^{1}$ The causes that drove this development are manifold, and it is not clear yet to what degree the humanities have actually been implicated in their own downfall. That right-wing political strategists such as Steve Bannon have used critical jargon to "deconstruct" the notion of government as we knew it, is indeed puzzling. Yet there is little evidence that humanist critical thinking is at the core of the current post-truth crisis, and that postmodernist efforts to rethink and question modernist forms of critique should be undone altogether.

5 And, finally, politics: In conclusion to my admittedly haphazard remarks on truth and post-truth, I ask, how could we possibly remedy the widespread disregard for public institutions, the demise of common sense, and the shattering of political dialogue, all three salient markers of our own, so-called post-truth era? Far from being an epistemological crisis, the current cultural transformation, I want to suggest, has already called forth far-reaching social and political consequences that need to be addressed. To hold the negative repercussions of cultural and technological change in check, salvage meaningful political dialogue in a largely digital, privatized media environment, in short, to make a strong case for truth-speaking as a form of critique and meaningful participation in politics, scholars in the humanities-their dwindling cultural authority notwithstanding-must weigh in on the issue at hand. If we agree that truth, as William James put it, "is made, just as health, wealth and strength are made, in the course of experience" (104), then not only is it imperative that as many as possible participate in the process of truth-making, but that they do so responsibly.

\section{Telling the Truth}

As Italian media theorist Chiara Cappelletto recently noted, there is a long prehistory to the current debate about truth and post-truth. In a paper delivered at a $2017 \mathrm{LMU}$ graduate conference on "Alternative Facts: Between Fact, Fiction, and Politics," Cappelletto emphasized that "the idea of an impersonal truth based on factual data is relatively recent in Western culture" (2). In classical oratory and rhetoric, for example, the factitiousness of an experience largely depended on the persuasive power of the orator who strives to present an argument in such a way that it appeared both rational and factual. Moreover, issues of truth cut across a wide variety of disciplines, such as epistemology, language philosophy, rhetoric, poetics, ethics, etc. Scholars in these fields are by and large disinclined to connect truth to some form of objective reality outside and beyond human intervention. Just consider Ferdinand de Saussure's structuralist theory of language. Rather than carrying innate, unchanging meaning (signified), words (signifier), depending on how they are used and in which context, can mean different things to different speakers/listeners. To disentangle the 'true' meaning of words can thus be treacherous. Far from representing reality "as is," the way humans use language, linguists tell us, has been crucial in shaping our respective notions of the real, including what we usually consider true or false.

7 From Plato to Poststructuralism, truth has been a conflicted issue. To distinguish between its various meanings as an, at once, epistemological, moral, and social 
construct has proven to be nearly impossible. Heidegger's discussion of truth and Being in Being and Time, titled "Dasein, disclosedness, and truth" (ch. 44), is a case in point. For here, Heidegger connects truth to our being-in-the-world, thereby grounding it in the human condition rather than in a preexisting, self-evident material world. Truth, according to Heidegger, is inextricably linked to Dasein and language. From an ontological perspective, there is no truth that predates Dasein, our being-in-the-world, and of someone who says "I" and who exists in time and place. For Heidegger, truth cannot be explained by way of a theory of correspondences alone (as in Aristotle, Parmenides, and others). Any speech act, even if merely reflective of an irrefutable aspect of human existence, such as, say, mortality or gravity, engages the interlocutor in myriad different ways, not all of them factual or verifiable. By the same token, Heidegger foregrounds the intuitive and performative level of language; and since our being-in-the-world is predicated on the vagaries of language, that is, "disguised and closed off by idle talk, curiosity and ambiguity" (BT 264), it is largely tied up with untruth rather than with truth: "Because Dasein is essentially falling, its state of being is such that it is in "un-truth"' (BT 264).

Heidegger's remarks on truth are complex, as they involve a number of linguistic and logical issues, such as negative assertive statements and the general problem of denotation. ${ }^{2}$ Prior to Heidegger's engagement, the latter has been famously discussed in Bertrand Russell's 1905 essay "On Denoting." Though primarily concerned with the mathematical and logical ramifications of denotation, Russell's essay is important because it argues that we often have access to what we consider as being true solely by way of denotation and not through direct knowledge. "There seems no reason," he writes, "to believe that we are ever acquainted with other people's minds, seeing that these are not directly perceived; hence what we know about them is obtained through denoting" (480). While all thinking has to start with direct experience, "it succeeds in thinking about many things with which we have no acquaintance" (480). Therefore, as Russell concludes, "such things as matter (in the sense in which matter occurs in physics) and the minds of other people are known to us only by denoting phrases, i.e., we are not acquainted with them, but we know them as what has such and such properties" (492). If Russell's remarks on denotation go against any theory of truth that posits a correspondence between an utterance and the object it is referring to, Heidegger's ontological approach is even more radical. In the aforementioned chapter of Being and Time, "Dasein, disclosedness and truth," he argues that to speak the truth can manifest itself in two, fundamentally opposite ways: for one, it can be an uncovering or dis-covering (ent-decken) and, for another, a covering-up, a "zu-decken" and "ver-decken" of Being.

9 Significantly if also somewhat paradoxically, both are crucial for an understanding of the relation of truth and Dasein, and both are inextricably intertwined. Even though there is a right way to speak the truth about an object or a thing, namely, the uncovering or dis-covering of its Being, quite frequently the coeval potential for coveringup, which for Heidegger is closely associated with the human condition itself, takes the upper hand. An unavoidable consequence of language, the covering-up has to be fought continuously and relentlessly. To reign in the human propensity for ambiguity and untruth, however, has nothing to do with coherence or correspondence, that is, with being right or wrong. As Heidegger repeatedly stresses, any statement about an abstract idea or an object is by necessity always true, either in relation to the person speaking or as the bringing forth, the foregrounding, of the mode of Being of the object 
spoken about. If a sign points towards something that is then designated, the relation between the sign and what is signified, as Heidegger insists, does in no way presuppose correspondence or verisimilitude.

What then distinguishes someone who speaks the truth from someone who utters a lie is the effort made by the former to curb the innate tendency of human speech to coverup, camouflage and to dissimulate. The truth or, as Heidegger calls it, demonstration ("Bewährung") of any speech activity correlates with its power to un-cover: "What is to be confirmed is that it discovers the being toward which it is. What is demonstrated is the discovering being of the assertion" (BT 201). ["Zur Bewährung kommt, daß das aussagende Sein zum Ausgesagten ein Aufzeigen des Seienden ist, daß es das Seiende, zu dem es ist, entdeckt" ( $S Z$ 218)]. Obviously, Heidegger's critique of defining truth as merely a function of the correspondence between verbal statements and non-verbal facts resonates with postmodern, poststructuralist theories of language. Yet it also differs significantly from, say, the deconstructionist approach to language which presupposes an ongoing playing of signifiers and, therefore, an ongoing deferral of meaning. For, if from an ontological perspective, Being and truth are mutually dependable, so are Being and non-truth: if "Dasein is in the truth," as Heidegger writes, then it is also true that "Dasein is in untruth" (BT 204).

11 Moreover, since Dasein is rooted "equiprimordially in truth and untruth" (BT 205) ["Das Dasein ist gleichursprünglich in der Wahrheit und Unwahrheit" (SZ 223)], the truth of Being always has to be wrested from Being itself ("abgerungen"), it is almost a kind of theft ("Raub"). This latter idea of "wresting" truth from Being, which evokes a strenuous, painful struggle for truth, is of utmost significance in light of the current post-truth debate. Because it suggests a willful attempt at un-covering layers of ambiguity and un-truth, to "speak the truth," for Heidegger, is to engage in a special kind of speech activity, driven by an intention to forcefully dis-cover the truth of Being. It should not go unnoticed, however, that Heidegger flat-out dismisses the idea of a subjective truth or any kind of solipsism regarding the truth of Being. Though closely bound-up with language and Being, truth as either un-covering ("entdeckend") or as a covering-up ("Verdeckung") exists independently of individual reasoning. If both of these modes of speaking represent different aspects of Being, the former, as Heidegger repeatedly emphasizes, should always be preferable to the latter. What is more, if a speech act that un-covers is in every respect more desirable than one that covers up, the former always necessitates an effort on the part of the speaker because she has to overcome the ambiguity arising from language itself. Speaking the truth, after all, is not about correspondences between words and objects or ideas; rather it turns on the ability of the speaker-and of what is spoken-to lay bare the truth of Being itself.

Insofar as Heidegger's ontological notion of truth as the "disclosedness" of Being stresses the performative aspects of a speech act that dis- or un-covers, it situates truth within the field of discourse. Important differences notwithstanding, Heidegger's analysis here dovetails with Foucault's interest in parrhesia (speaking the truth) which has been the focus of a series of six lectures delivered at the University of California, Berkeley, titled "Discourse and Truth." 3 As Foucault points out at the outset of these lectures, his objective is not to define truth as such, that is, how someone knows that a given statement is either true or false. What he looks at instead is speaking-the-truth as discourse, an auto-referential speech act the Greeks called parrhesia. Foucault actually uses the broader, less technical term "speech activity," for parrhesia, as he takes pains 
to explain, does not simply mean "speaking the truth." If translated literally, parrhesia means "to say everything," not to withhold anything you have to say and to say it in the most direct and straightforward fashion. Parrhesia thus refers to a speaker and the way he speaks; and since he is not holding back anything he has in his mind, he opens himself up to an interlocutor by way of discourse (to retool Heidegger's notion of disclosedness, you could say he dis-closes himself to the interlocutor). Yet in order to use parrhesia and become a parrhesiastes, a specific discursive context is required. Foucault lists three characteristics that are needed so that the idea of parrhesia applies. First, danger: "The parrhesiastes is someone who takes a risk" 4 ; if a politician speaks the truth in spite of the risk of losing his or her popularity because what he or she has to say is against the public opinion then he or she uses parrhesia; second, criticism: "The function of parrrhesia is not to demonstrate the truth to someone else, but has the function of criticism: criticism of the interlocutor or of the speaker himself"; and third, duty: consider a speaker who has the option to either speak freely or not to speak at all (i.e. who does not speak under pressure or torture); if he or she then says something that is critical of someone else who is more powerful than the speaker him- or herself merely because he or she feels it to be his or her duty, then and only then, Foucault argues, the speaker can be called a parrhesisastes.

Both Heidegger's definition of truth as a violent, strenuous un-covering of the hidden layers of Dasein and Foucault's interest in parrhesia as a dangerous yet dutiful intervention of an individual into public discourse resonate in important ways with the current post-truth crisis. Both refrain from exploring the possibility of knowing the truth as such; rather, they ask about the conditions of speaking the truth, of its potential, in Heidegger's case, to bring to light important yet hidden aspects of our being-in-the world and, in Foucault's discussion of parrhesia, of why it matters that we speak truly even if against our own best interest. Speaking the truth thus appears to be much more-or, if you want, less-than merely an epistemological issue, it becomes a social imperative. Heidegger's more opaque ontological approach, one could argue, may have served well to camouflage his own fatal implication in totalitarian politics during his term as Rektor of the University of Freiburg. Because it stresses un-truth as an indelible ingredient of truth itself, it could be easily misread as an all-out opportunistic, overly malleable concept. Like Foucault, however, he stresses the discursive aspects of speaking truthfully and, what is more, the fact that truth is not some kind of "ready-made" entity to be either chosen or overlooked. For both, Heidegger and Foucault, truth is part and parcel of the act of speaking out against all odds, and it is only then, under the arduous conditions of criticism, danger, and duty, that truth as discourse is forged from a world of un-truth and covering-up.

\section{Know It Yourself}

14 As many have noted, anti-professional attitudes, coupled with a profound suspicion of institutions of higher learning, are on the rise. ${ }^{5}$ According to a 2017 Pew Research Center poll, a majority of Republicans and Republican-leaning independents in the US now believes that "colleges and universities... have a negative effect on the country" (quoted in Green, NYT). In a recent article in The Federalist, political scientist Tom Nichols even depicts a large-scale sell-out of knowledge amounting to what he calls the "death of expertise." The ramifications of this latest distrust in expertise are 
considerable, as it extends far beyond academic institutions to affect almost any form of professional training. The reasons for this development are manifold. If the easy availability of rudimentary professional knowhow via online sources has fueled a new "do-it-yourself"/"know-it-yourself" amateur culture, cultural and institutional factors also conjoined to spawn the dismantling of professional knowledge. ${ }^{6}$ In the US, antielitism and anti-intellectualism have, for a long time, shaped a cultural-industrial complex determined to undermine professional expertise and the authority of institutionalized knowledge. ${ }^{7}$

15 Yet, anti-professionalism has also grown from within the academy itself. Long before Trump lionized the widespread populist attacks on science and the university, the French historian of science, Bruno Latour, argued that the erosion of expertise has been fostered, at least in part, from within the humanities and the critical sciences themselves. Remarkably prescient of recent developments, Latour's aforementioned 2004 essay "Why Has Critique Run out of Steam" takes issue with an already widening gap between the world of science and the world of Joe-the-plumber, that is, blue-collar America. "What has become of critique," Latour asks, "when there is a whole industry denying that the Apollo program landed on the moon?" (228). And what "if explanations resorting automatically to power, society, discourse had outlived their usefulness and deteriorated to the point of now feeding the most gullible sort of critique?" (229-30). If the former already speaks to an increasing onslaught of fake news and conspiracy theories, the latter raises considerable doubt regarding critical practices within the humanities that have actually ceased to be critical at all, and instead have championed knee-jerk responses ("power, society, discourse") for almost every social and cultural issue there is.

Obviously, Latour could not have known that Stephen Bannon and other right-wing strategists would use poststructuralist jargon to powerfully "deconstruct" American government. As he noticed early on, however, for conservatives to raise doubt about the scientific evidence of global warming, a critique Latour's own writing had been complicit in administering, offered an inroad to eventually dismiss scientific expertise altogether. Though for science studies, a field he had helped establish, "the question was never to get away from facts but closer to them, not fighting empiricism but, on the contrary, renewing empiricism" (231). Yet it's largely rationalist approach to the contrary, the critical study of science has paved the way for the most egregious and dangerous anti-enlightenment thinking. "The mistake we made," Latour grudgingly admits, "the mistake I made, was to believe that there was no efficient way to criticize matters of fact except by moving away from them and directing one's attention toward the conditions that made them possible" (231).

17 To remedy the loss of a shared experience of reality triggered by identity politics and accompanying relativist concepts such as "situated" knowledge (Haraway), ${ }^{8}$ Latour calls for a return to a new "realist" attitude: if critical thinking, and, by implication, the humanities at large, should be able to renew itself and thus have a future, "it is to be found in the cultivation of a stubbornly realist attitude..., but a realism dealing with what I call matters of concern, not matters of fact" (231). Though reality is by no means defined entirely by matters of fact, facts do matter in that they are often political renderings of matters of concern or, to a lesser extent, "states of affairs" (232). Latour clearly describes his own effort at debunking certain myths surrounding the history of science as closely wedded to Enlightenment thought. Yet while enlightenment thinkers 
originally used scientific facts to criticize older, premodern beliefs and illusions, over time these facts have been used to also cover up some of science's own innate prejudices and vested interests. As of yet, it is by no means clear whether we can devise "another powerful descriptive tool that deals this time with matters of concern and whose import then will no longer be to debunk but to protect and to care?" (232). In other words, can matters of concern be reframed so that they include more than just one fractured version of reality, and become a powerful driving force in today's globalized yet hopelessly divided world?

Whatever this new kind of realism might entail, it should not be of the same ilk as the so-called "new humanities," proffered by Harvard psychologist Steven Pinker in a controversial 2013 piece for the New Republic, titled "Science is Not Your Enemy." Pinker and his conservative fellow critics envision a field stripped of its idealist trappings and so redefined that it is decidedly more receptive to scientific methodology. To thus "scientize" the humanities, however, is not a solution but yet another attempt at cementing the waning influence and public reputation not merely of the soft sciences but of the university at large. "Being is in no way identical with reality or with a precisely determined actuality," Heidegger writes in an epilogue to his essay "The Thing." "In thinking of Being, it is never the case that only something actual is represented in our minds and then given out as that which alone is true" (181). It is this latter kind of self-critical inquiry into the conditions of Being that the humanities of old-and, frankly, all of enlightenment thinking-have been good at. Latour is right in arguing that the task of the humanities is to return to a new sense of realism, a realism of concern, or as Heidegger would put it, a realism that "examines as it listens" (184). To follow such a path, Heidegger knew all too well, takes both courage and practice in going. Yet practice also needs craft, and so to stay on the path, as Heidegger writes in a letter to a young student, we need to learn unswervingly "the craft of thinking, yet erring."

\section{Common Sense}

19 It should have become sufficiently clear by now that the idea of a post-truth cultural environment makes little sense. What has changed significantly with the onslaught of "digimodernism," Alan Kirby's term for the now dominant form of neoliberal, digitized global capitalism, is by no means the disappearance of truth as we know it..$^{10}$ Rather, what has been "covered up," to retool Heidegger's wording in Being and Time, is our appreciation and understanding of the pivotal role of parrhesia, of speaking the truth even in the face of danger and of negative consequences for the speaking self. This, then, brings me to the issue of politics and of what could be possibly done about the alarming demise of common sense, a term I use here in its broadest and most democratic meaning, that is, as the shared experience of reality and of the values that we attach to this reality.

If anti-professionalism and the death of expertise have been conducive to further diminish the reputation of the humanities and, to a great extent, of the sciences in general, the conspicuous absence of any meaningful political alternative to late (digital) capitalism has further eroded our willingness to speak out in public, to become (again) -as Foucault has it-parrhesiastes. However urgent we now think this issue is, the crisis of public intervention in politics, as Richard Sennett has shown, has been coeval with 
the birth of modern society itself. ${ }^{11}$ In fact, the erosion of the public arena as a performative space where political decision-making is both enacted and acted out dates back to the late eighteenth and early nineteenth century when the public domain has been increasingly emptied out of its earlier, social meaning. Sennett describes these transformative changes in the public domain as the substitution of the public by a private self. In other words, even though the enlightenment has incubated, by way of the printing press and the burgeoning new metropolitan spaces, a powerful culture of public discourse and public performance, by the end of the nineteenth century it had been almost completely layered over by an inward-looking culture of intimacy.

In 1977, the year his landmark study was originally published, Sennett could have hardly envisioned the new public spaces opened up by social media and the internet. Yet his principle argument, it seems to me, still rings true. The lenses through which most of us view the world are now almost entirely filtered by private, intimate concerns. By the same token, we consider the taking on of a public office, our membership in a church, a trade union, or a political party, and even voting itself, asat best-a formal obligation and-at worst-a dispensable nuisance. "In a society where intimate feeling is an all-purpose standard of society," Sennett explains, "experience is organized in two forms which lead to... unintended destructiveness. In such a society the basic human energies of narcissism are so mobilized that they enter systematically and perversely into human relationships. In such a society, the test of whether people are being authentic and 'straight' with each other is a peculiar standard of market exchange in intimate relations" (8).

Sennett wrote The Fall of Public Man against the backdrop of the countercultural revolution of the 1970s, which heavily emphasized individual authenticity and personal expression. And yet, it would be difficult to think of a more appropriate description of the social-cultural environment that enabled the Trump presidency and that many now call the post-truth era. If politics today ostensibly encroach every nook and cranny of individual self-expression (just think of academic 'safe' spaces and the ongoing policing of the self by way of social and commercial pressure), both political reasoning and the willingness to speak out and criticize the powers that be, have become conspicuously dysfunctional. Multiple forces have driven this development, yet it is equally obvious that for too long societies in the West have stressed individual experience at the expense of public responsibility. When Thomas Paine, at the beginning of Common Sense (1776), calls government the "badge of lost innocence" because it is an intrinsically evil force yet necessary to "restrain our vices" (69), he not only recognizes the volatility of the human psyche. What he also acknowledges is the need for a social contract and the division of power as cornerstones of any modern society. All modern nations have delegated, though to varying degrees, executive power to the government, juridical power to the courts, and the power to inform and enlighten about the state of affairs to the press. Simultaneously, they have either actively created or at least tolerated public spaces that provide room for individual expression and participation in decisionmaking processes.

That in a democracy a small number of politicians yield executive power over their fellow citizens is a calamity; yet one, as Paine argues, that is acceptable because it ultimately guarantees freedom and security. The consenting of the majority of citizens to "leave the legislative part to be managed by a select number chosen from the whole body, who are supposed to have the same concerns at stake which those have who 
appointed them, and who will act in the same manner as the whole body would act were they present" (CS 7-8) is based, for one, on the condition that this body of representatives is being elected into office; and for another, it rests on the assumption that there will be a common interest among every part of the community. To ensure that the elected "might never form to themselves an interest separate from the electors, prudence will point out the propriety of having elections often" (CS 8). The rationale here is to avoid division by interest and status, and instead to strengthen the interconnectedness-what Paine calls "mingling"-of both parties, so that they mutually support each other.

At the outset of modern society there has thus been a shared understanding of the wisdom of certain rules and norms that were in place for the common good. There has also been widespread agreement that the "truth" of democracy and of modern government can never be stated in abstract, objectified terms. If absolute truth obtained as an important social goal, it was unavoidably inflected "by the inability of moral virtue to govern the world" (CS 8). Yet like many enlightenment thinkers, Paine was convinced that "however our eyes may be dazzled with show, or our ears deceived by sound; however prejudice may warp our wills, or interest darken our understanding, the simple voice of nature and of reason will say, it [i.e. to be governed in that way] is right" (CS 8). It is by virtue of reason or common sense alone that we subscribe to the social contract that undergirds all modern political institutions. What this also means, however, is that one should avoid any form of dishonesty while holding public office, regardless of whether it is directed towards oneself or towards the electors. Once a man has so far "corrupted and prostituted the chastity of his mind, as to subscribe his professional belief to things he does not believe," Paine later wrote in The Age of Reason, "he has prepared himself for the commission of every other crime" (AR 8). What is more, it would be impossible to calculate "the moral mischief... that mental lying has produced in society" (AR 8). This notion of an almost moral obligation to be true to oneself also informs Foucault's parrhesiastes. Far from ushering in a world of multiple and therefore of no truth at all, to avoid "mental lying," in both Paine and Foucault, enables political praxis because it allows the speaker to act responsibly in the public arena.

There is plenty of room to speculate why the ideals of mental honesty and of parrhesia have become totally corrupted. Or, why many have lost confidence in the institutions initially set up to support and guarantee individual freedom. "I do not believe," Paine states in The Age of Reason (1794), "in the creed professed by the Jewish church, by the Roman church, by the Greek church, by the Turkish church, by the Protestant church, nor by any church that I know of. My own mind is my own church" (AR 8, my emphasis). The ambivalence of this kind of idealization of personal authenticity is obvious. Moreover, it reflects much larger contradictions well embedded within Enlightenment thinking itself. As Peter Gay points out, "the state within, and the state system as a whole appeared to have aims incompatible with enlightened ideals" (450). If Enlightenment ideas appealed to a large extent to individual reasoning independent from and often at odds with institutionalized knowledge and tradition, political formations, on the other hand, demand the persistence of habit, the burden of deference, and the accountability of rules. Put differently, intellectual self-reliance and the exigencies of the state are often-if not mutually exclusive-at least difficult to integrate. 
This also means that the tendency towards ever greater civil division, as well as a growing tension between the state and its constituents, is firmly nested within the intellectual foundations of modern democratic society itself. "As for morality," Paine proudly stated in The Age of Reason, "the knowledge of it exists in every man's conscience" (AR 183). The enlightenment's dependence on science and factual evidence to the contrary, the same could be said of the notion of truth. It is in this context that the companion idea of "common sense" truly matters. As guarantor of collectively shared values, duties, and morals, common sense-in its broadest and most inclusive understanding-could guide us through the maze of subjective experiences and the political fallout of the modern culture of intimacy (including its latest version as posttruth). That we collectively agree on the kind of reality we privilege and cherish, it seems to me, is now more imperative than ever. For the demise of common sense does not bode well-for the university, for society, and for the future of mankind as we know it.

\section{BIBLIOGRAPHY}

Anastas, Benjamin. “The Foul Reign of Emerson's ‘Self-Reliance.” The New York Times, 2 Dec. 2011.

Cappelletto, Chiara. Alternative Facts, Fiction, as if. Unpublished working paper, LMU Graduate School of Language and Literature, Munich, November 2017, pp. 1-5.

Carey, Benedict. “'Fake News': Wide Reach but Little Impact, Study Suggests.” The New York Times, 2 Jan. 2018.

Fish, Stanley. “Anti-Professionalism.” New Literary History, no. 17, pp. 89-108.

Foucault, Michel. Discourse and Truth \& Parresia. Edited by Henri-Paul Fruchaud and Daniele Lorenzini, translated by Nancy Luxon, U of Chicago P, 2019.

Gay, Peter. The Enlightenment: The Science of Freedom. Norton, 1969.

Green, Joshua. "No One Cares About Russia in the World Breitbart Made.” The New York Times, 15 July 2017.

Harraway, Donna. "Situated Knowledges: The Science Question in Feminism and the Privilege of Partial Perspectives." Simians, Cyborgs and Women: the Reinvention of Nature, edited by D. Haraway, Routledge, 1991, pp. 183-202.

Heidegger, Martin. “The Thing.” Poetry Language Thought, translated by Albert Hofstadter, Harper, 1971, pp. 163-184.

---. Being and Time. Translated by John Macquarrie and Edward Robinson, Blackwell, 1962.

James, William. “Lecture IV: Pragmatism's Concept of Truth.” Pragmatism, edited by W. James, Harvard UP, 1975, pp. 95-113.

Kirby, Alan. Digimodernism: How New Technologies Dismantle the Postmodern and Reconfigure Our Culture. The Continuum International Publishing Company, 2009. 
Lane, Neal F., and Michael Riordan. "Trump's Disdain for Science.” The New York Times, 4 Jan. 2018.

Latour, Bruno. "Why Has Critique Run out of Steam? From Matters of Fact to Matters of Concern." Critical Inquiry, Winter 2004, pp. 225-248.

Nichols, Tom. "The Death of Expertise." The Federalist, 17 Jan. 2014.

Milchman, Alan, and Alan Rosenberg, editors. Foucault and Heidegger: Critical Encounters. U of Minnesota P, 2003.

Paine, Thomas. Common Sense. Prometheus Books, 1995.

---. The Age of Reason. Prometheus Books, 1984.

Pinker, Steven. “Science Is Not Your Enemy.” The New Republic, 7 Aug. 2013.

---. Enlightenment Now: The Case for Reason, Science, Humanism, and Progress. Viking, 2018.

Russell, Bertrand. “On Denoting.” Mind, vol. 14, no. 56, Oct. 1905, pp 479-493.

Sennett, Richard. The Fall of Public Man. Knopf, 1977.

Slavik, Angelika. “Das kann ich doch auch.” Süddeutsche Zeitung, no. 26, 30/31 Dec. 2017.

Willer, Malte. "Der Wahrheitsbegriff in Martin Heideggers Sein und Zeit. Versuch einer Neubeleuchtung." Philosophisches Jahrbuch, vol. 113, no. 1, 2006, pp. 78-98.

\section{NOTES}

1. Cf. Lane and Riordan, "Trump's Disdain for Science;" Latour, "Why Has Critique Run out of Steam? From Matters of Fact to Matters of Concern."

2. For a detailed, philosophical assessment of Heidegger's notion of truth in Being and Time, see, in German, Willer, "Der Wahrheitsbegriff in Martin Heideggers Sein und Zeit. Versuch einer Neubeleuchtung."

3. For a discussion of the differences and continuities between Heideggerian ontology and Foucauldian genealogy and discourse analysis respectively, see the essays in: Alan Milchman and Alan Rosenberg, editors, Foucault and Heidegger: Critical Encounters.

4. All quotations of "Truth and Discourse" are from the following online source, accessed on 22 July 2019: www.naturalthinker.net/trl/texts/Foucault,Michel/Foucault\%20-\%20Discourse \%20and\%20truth.pdf.

5. See Fish, Slavik, Anastas, and Nichols.

6. Cf. Slavik "Das kann ich doch auch."

7. See Anastas, "The Foul Reign of Emerson's ‘Self-Reliance."

8. See Donna J. Haraway, "Situated Knowledges: The Science Question in Feminism and the Privilege of Partial Perspectives."

9. Epilogue to "The Thing"; "A Letter to a Young Student, Freiburg i. Br. 18 June 1950" (184).

10. See, among others, Alan Kirby's 2009 analysis Digimodernism: How New Technologies Dismantle the Postmodern and Reconfigure Our Culture.

11. Cf. Sennett, The Fall of Public Man. 


\section{ABSTRACTS}

This essay argues that there is no such thing as post-truth. We are by no means in the middle of an unprecedented epistemological crisis that keeps us from telling right from wrong. Rather, what we currently witness is a major breakdown of the institutions and mechanics of democratic society, triggered by an encompassing technological transformation that affects both our public and private lives. Even if the challenges for rational public discourse are real, they should not be countered by philosophy but by concerted, serious interventions in the political arena. This essay's approach to the issue of post-truth, therefore, is threefold: First, it looks at how most of us in the West have come to agree on certain truths about truth. Second, since the notion of posttruth is often invoked to expose someone who fails to speak the truth (rather than to demote the concept of truth altogether), it refers to the Greek tradition of parrhesia as discussed by the late Michel Foucault. And thirdly, this essay comments on the alarming rise of anti-professionalism. Long before neoconservatives waged war on the university, the erosion of expertise has been fostered, according to Bruno Latour, by forces unleashed within the humanities itself. Yet there is little evidence, this essays concludes, that humanist critical thinking is driving the current post-truth crisis and that postmodernist efforts to rethink and question modernist forms of critique should be undone altogether.

INDEX

Keywords: concept of post-truth; modernist vs. postmodernist critique; crisis of the humanities; anti-professionalism; Michel Foucault and the politics of parrhesia

\section{AUTHOR}

\section{KLAUS BENESCH}

Klaus Benesch is Professor of English and American Studies at LMU University of Munich. From 2006 through 2013, he was Director of the Bavarian American Academy (Munich). He served as member of the Editorial Board of the Encyclopedia of American Studies Online (published by Johns Hopkins University Press) and is general editor (with Miles Orvell, Jeffrey Meikle, and David Nye) of "Architecture/Technology/Culture," a monograph series published by the University of Pennsylvania Press. Major publications include: Walking and the Aesthetics of Modernity. (editor; Palgrave, 2016); Rethinking the American City: An International Dialogue (editor; U of Pennsylvania P, 2014); Culture and Mobility (editor; Winter, 2013); Romantic Cyborgs: Authorship and Technology in the American Renaissance (2. ed., paperback; U of Massachusetts P, 2009); Scientific CulturesTechnological Challenges: A Transatlantic Perspective (editor; Winter, 2009); The Power and Politics of the Aesthetic in American Culture (editor; Winter, 2007); and Space in America: Theory, History, Culture (editor; Rodopi, 2005). 